\title{
FACTORS OF TOURISM'S COMPETITIVENESS IN THE EUROPEAN UNION COUNTRIES
}

\author{
Vanda Maráková, Tadeusz Dyr, Anna Wolak-Tuzimek
}

\section{Introduction}

Tourism is currently among the most dynamically growing branches of the national economy and a major sector of employment. It is an important area of activity of contemporary society, as well as one of the largest and most profitable industries globally.

Tourism competes with acquiring tourists and its competitiveness is based on the attractive natural resources and elements of cultural heritage as well as their adequate exposure and use (Pompurová \& Šimočková, 2014). The advantage in this respect is of particular significance to regions in an economic slump, which stand to find a source of additional or key income and reduced unemployment.

Review of various literature points to significant dependence between the development of tourism and competitiveness of states and regions. The results of literary reviews and empirical research are presented in this article, including statistical analysis of these dependences. The empirical research focuses on both factors constituting sources of competitive advantage and its outcomes. These factors include the capacity of tourist accommodation establishments, their arrivals and their average expenditure during tourism trips. This includes both domestic and outbound trips. The competitiveness of the European Union member states is based on three factors representing output competitiveness, i.e. GDP, gross value added and final consumption expenditure. The data are adopted from official public statistics of the European Union, available with Eurostat.

It is the objective of the paper to present and evaluate the dependences between competitiveness of the European Union member states and selected factors determining competitiveness of tourism in these states.
The following hypotheses have been adopted for the purposes of this objective:

$\mathrm{H} 1$ : Availability of accommodation establishments, a major factor of a regions' tourist competitiveness, is highly varied throughout European Union member states.

$\mathrm{H} 2$ : There is a high, statistically significant correlation between availability of accommodation establishments and tourism arrivals in a given country in the European Union member states.

$\mathrm{H} 3$ : There is a high, statistically significant correlation between competitiveness of these states and expenditures on tourism services in the European Union member states.

These hypotheses have been verified by means of Hellwig's method of constructing taxonomic indices based on partial diagnostic variables. It helps to rank states in respect of various aspects under discussion as determined by diverse diagnostic variables.

\section{Competition and Competitiveness}

Competition and competitiveness are present wherever there are private ownership as a means of production and an economy of goods. They are fixtures and core parts of the market economy. They are not identical, however.

Competitiveness is determined by a number of factors, both short- and long-term. To be competitive, an entity must first stand out in the market - be recognised.

"Competitiveness is given in various definitions in literature. It most commonly denotes the ability of certain entities to compete in a given market segment. The notion of competitiveness may be applied to each degree of aggregation, i.e. to an individual product, an enterprise, a sector, industry, region or the national economy" (Nawrot \& Zmyślony, 
2009 , p. 55-56). Therefore, both a business and a territorial unit like a city, community or region can be said to compete. However, competition among businesses is the most important instance of the phenomenon in connection with economic development.

Competitiveness of enterprises is based on and is a part of competition. Thus, competitiveness can be described as a firm's ability to compete with other enterprises. It also has a variety of other senses, though.

In economic terms, competition is rivalry among entrepreneurs for profits from the sale of goods and services, for selling and supplying markets and for workers. It can be developed provided there are independent enterprises in the market, there are agents responding to market signals and impulses and both enterprises and agents have free access to the market.

"Competitors attempt to realise similar goals, which means actions taken by some interfere with or even prevent others from attaining the same objectives" (Wolak-Tuzimek et al., 2015, p. 37).

Competitiveness is multi-dimensional as it concerns states (macro scale), sectors, industries, parts of economy (mezzo scale), groupings of countries (mega scale), enterprises (micro scale), commodities or services (micro-micro scale). "Competitiveness as a microeconomic category relates to organisations, e.g. enterprises or plants. It is multi-dimensional and perceived in relations among: a business entity, its potential, opportunities and skills versus market structure and strategic opportunities available there" (Markova et al., 2014, p. 88).

Particular definitions of competitiveness vary, as illustrated by the table below.

Competition exists in every sphere of economic life. It causes both negative and positive economic effects. When the particular definitions of competitiveness offered by literature are compared, it can be noted the concept means both a capacity for rivalry with competitors and a current competitive standing. At present, competition is not only rivalry but also an opportunity for cooperation between business partners.

Competitiveness is regarded as a natural development in economic life and the key source of wealth. It promotes not only rivalry among competitors but also cooperation as they jointly look for the best solutions to problems. Today, competition is not only rivalry, but also an opportunity for cooperation between business partners as well (Ślusarczyk, 2011).

\section{Tab. 1: Selected definitions of competitiveness}

\begin{tabular}{l|l}
\multicolumn{1}{c|}{ Author } & \multicolumn{1}{c}{ Definition } \\
\hline K. Markovics & $\begin{array}{l}\text { Competitiveness means, essentially, "the liability and skill for market } \\
\text { contention and the skill for position gained and a permanent commitment } \\
\text { that are indicated especially by successful expansion of business, market } \\
\text { share and profitability". }\end{array}$ \\
\hline F. A. von Hayek & $\begin{array}{l}\text { A procedure of discovery in conditions where there is full freedom of action } \\
\text { in the market. }\end{array}$ \\
\hline A. L. Alarcon & $\begin{array}{l}\text { Ability of a region, industry or individual enterprise to compete in markets } \\
\text { where they operate in parallel with improvement in living standards of } \\
\text { society. }\end{array}$ \\
\hline M. E. Porter & $\begin{array}{l}\text { Competitiveness of an economy is measured as productivity as a value of } \\
\text { products by a unit of labour. The author suggests defining determinants of } \\
\text { productivity for particular sectors and enterprise groupings. }\end{array}$ \\
\hline R. Huggins & $\begin{array}{l}\text { Competitiveness is the capacity for using individual, specific and valuable } \\
\text { resources which are difficult for competitors to imitate. }\end{array}$ \\
\hline The Global & $\begin{array}{l}\text { Competitiveness is a set of institutions, principles and factors determining } \\
\text { standards of national productivity. }\end{array}$ \\
\hline
\end{tabular}




\section{Tab. 2: Positive and negative effects of competition}

Positive effects of competition

Competitors occasionally support market

segments unattractive to other businesses.

\section{Negative effects of competition}

It reduces the numbers of jobs and living standards in countries losing the competitive struggle. Differences of living standards in particular global regions are expected to widen due to growing income disparities.

If everyone competes against everybody else, the value of competitiveness is lost.

by financing market development. Such firms may incur some costs of standardising products or approving new technologies. Their image (if they are prestigious) can in addition improve reliability of an entire sector.

Competitors jointly incur costs of countering new
enterprises in a sector.
enterprises in a sector.

Competition is the key driver of cost reduction, product improvement, and technological change.
It only reflects one dimension of social and human history, i.e. the spirit of rivalry. It boosts effectiveness of actions at the expense of human relations.

By determining acceptable directions, it restricts the process of individual and social life and development. Excessive competition leads to its mass rejection by the public and to polarisation of social groups.

Competition provides continuous value: in the field of production, by cutting unit costs without lowering quality; in respect of work and management methods, it boosts effectiveness.

Competition increases value by continuous verification of products and services offered by an enterprise to improve them.
Representatives of competing enterprises corrupt state officials, who may make decisions favouring these enterprises, ,spoiling' the public image of the state and its representatives. Such bribery is a result of inefficiency of state institutions.

Discrediting competitors and their products before the public by unfair advertising or other illegal measures.

Competition creates innovation, which is evident in the launching of new products, among other things.

\section{Tourism as a Form of Economic Activity}

Tourism is a multi-dimensional, psychological, social, economic, geographical and cultural phenomenon. Therefore, the very notion of tourism and its definitions have long been controversial. These debates concern not only the question which trips should be considered as tourism but also the broader issues of defining tourist demand and supply. In extreme cases, tourism is interpreted either as travel that involves sightseeing and wandering for pleasure and in the free time (the narrow and most common notion of tourism) or as any travel that involves an influx of funding in the case of arrivals and its outflow in the case of departures (the broad approach represented by some travel analysts) (Gilbert, 1990). Several definitions of tourism are presented below.

The development of tourism may be evaluated on both the global, national, regional and local scales. In this economic perspective, tourism is a complex market of goods, capital and labour where a variety of services are exchanged (Cabaj \& Kruczek, 2007). Demand or desire of the public to spend their leisure in a variety of ways, is the key to development of tourism seen in this light.

Tourism is an important and contemporary area of economic and social life. Tourist activity 


\begin{tabular}{l|l}
\multicolumn{1}{c|}{ Author } & \multicolumn{1}{c}{ Definition } \\
\hline W. Hunziker & $\begin{array}{l}\text { All relations and developments associated with travel and stay in a location } \\
\text { by arrivals if not motivated by the desire to settle and therefore unrelated } \\
\text { to any gainful activities. }\end{array}$ \\
\hline $\begin{array}{l}\text { R. W. McIntosh \& Ch. R. } \\
\text { Goeldner }\end{array}$ & $\begin{array}{l}\text { The sum total of phenomena and relations arising from interactions } \\
\text { between tourists, service providers, governments and receiving } \\
\text { communities in the process of attracting and hosting tourists and other } \\
\text { visitors. }\end{array}$ \\
\hline K. Przecławski & $\begin{array}{l}\text { All geographical mobility associated with voluntary, temporary changes } \\
\text { of location, rhythm, environment, living and personal contact with the } \\
\text { (natural, cultural or social) visited environment. }\end{array}$ \\
\hline WTO & $\begin{array}{l}\text { All activities by individuals who travel and stay outside of their everyday } \\
\text { surroundings for an uninterrupted maximum of a year for rest, work } \\
\text { or other purposes. }\end{array}$ \\
\hline
\end{tabular}

Source: Hunziker (1951, p. 1); McIntosh and Goeldner (1986); Przecławski (1996, p. 30); Panasiuk (2006, p. 24)

is a measure of living standards and an indicator of progress in societies. The development of tourism is a major driver of socio-economic dynamics. Its importance is demonstrated by its high capacity for generating new jobs, improvement of local life quality and enhancing competitiveness of regions. In parallel, tourism contributes to the discovery of the most precious cultural and environmental resources that, once highlighted, improves the internal and external image of a country, region or location.

Tourism is among the fastest growing sectors of the economy as it reflects dynamics and scope of coordinated social development and sustainable progress. A number of countries, provinces and regions have achieved well-rounded social and economic growth by developing the tourist economy and the range of necessary support measures including a complementary infrastructure and an active well-educated society. In doing so, they organise an adequate living standard and fulfil the basic social requirement.

Tourism is the starting point for the development of regions for several reasons.

1. As a service, it requires significant human capital, which is rare in the global economy. Tourism cannot work without the human factor, hence its huge impact on the job market.

2. Growing revenue in this sector translates into genuine creation of new jobs.

3. It is a powerful instrument of regional policies that eliminates social and economic disparities as it transfers demand from rich to less wealthy and less developed regions.

4. It is crucial in adding value that stimulates and boosts the morale of the local communities.

5. It helps to reconcile nations in conflict, overcome stereotypes, and broaden knowledge and intellectual development.

6. It's a perfect stimulator of local communities and regions.

The 2010 Madrid Declaration stresses the need to improve competitiveness of the tourism sector in line with principles of sustainable development and affirms the EU's goal for tourism generated added value. This achieved through an integrated approach to tourism and supplemental actions of the member states. Actions for tourism should focus around four pillars (Polska Organizacja Turystyczna, 2012, p. 19):

1. Stimulating competitiveness of the tourist sector in Europe,

2. Support for development of high-quality sustainable and responsible tourism,

3. Consolidation of Europe's image as a set of quality tourist destinations in line with principles of sustainable development,

4. Full use of the potential of various EU policy areas and financial instruments for the development of tourism.

Tourism is among the fastest-growing sectors of the global economy as confirmed 
by statistics of the World Tourism Organisation (UNWTO) and World Travel and Tourism Council (WTTC), recording a steady, uninterrupted rise of both numbers of tourists and tourism revenue after the Second World War.

\section{Sources of Competitive Advantage in Tourism}

Each entity in the market attempts to gain a competitive advantage, that is, to stand superior to other competitors. It is a relative indicator of economic operations - it helps an entity to offer products or services conforming to customer expectations as being better than those offered by competitors. This product can be of better quality, lower price, better service or more complete satisfaction of the customers' needs.

Specialist literature provides a range of definitions of competitive advantage. Some interesting interpretations of the term are given below:

- "All that distinguishes the products of a firm or the firm itself to its advantage from its competitors in the eyes of end users." (Fahey, 1989, p. 18).

- Something owing to which a firm achieves better performance or simply does things better than its competitors (Aaker, 1989).
- "Ability of an entity to do something its competitors are incapable of doing, or at least doing it better than them." (Rue \& Holland, 1986, p. 432).

- "Strengths of an organisation compared to its present and probable future competitors." (Stoner, 1982, p. 113).

- "Ability to pursue a present and future strategy that competitors are unable to realise." (Barney, 1991, p. 102).

To gain a lasting competitive advantage, an entity should offer more attractive services or products than those proposed by the competition.

A competitive advantage is increasingly gained owing to factors which assure additional benefits from launching of new-quality products and services which provide for a highly profitable flexibility of demand (Sieradzka, 2015).

Specialist literature encompasses two main trends analysing sources of competitive advantage, are demonstrated in the following table.

M. E. Porter (2001) points to four sources of competitive advantage:

- Demand conditions, in particular, demanding customers and their needs that emerge earlier than elsewhere.

- Presence of related and supporting sectors.

\section{Tab. 4: Main lines of thinking on sources of competitive advantage}

\begin{tabular}{l|l}
\multicolumn{1}{c|}{ Trend } & \multicolumn{1}{c}{ Description } \\
\hline & $\begin{array}{l}\text { - Based on analysing the specific nature of a sector where an entity } \\
\text { operates. }\end{array}$ \\
$\begin{array}{l}\text { Positional approach } \\
\text { (industrial organization } \\
\text { theory) }\end{array}$ & $\begin{array}{l}\text { - Significance of the environment and its effect on decisions and actions are } \\
\text { This approach was developed and propagated in the 1980s by M. Porter, } \\
\text { who believed an entity's capacity for dealing with competitive forces } \\
\text { better than other market players do is the starting point for a competitive } \\
\text { advantage. In this context, a firm's competitiveness depends on the intensity } \\
\text { of five competitive forces in a sector. }\end{array}$ \\
\hline $\begin{array}{l}\text { Resource based } \\
\text { view of the firm }\end{array}$ & $\begin{array}{l}\text { - Competitive advantage is a result of unique resources (skills, } \\
\text { competences) of an entity, including knowledge, organisation of operations, } \\
\text { management methods, experience, brand and patents that help to prevent } \\
\text { or restrict actions by the competition. } \\
\text { - The resultant competitive advantage is attained as competitors find it } \\
\text { difficult to acquire comparable or similar resources determining success. } \\
\text { Analyses in accordance with the resource-based view not only assess key } \\
\text { competences but also identify new requirements, new products that will } \\
\text { provide a foundations for building new key competences. }\end{array}$ \\
\hline
\end{tabular}


- Production factors that encompass both tangible and intangible resources.

- Context of strategy and business rivalry, that is, legal regulations, incentives and customs governing types and intensity of local rivalry.

In reference to the tourist service sector, the first three sources of competitive advantage listed above are well recognised by the theory of tourist region.

Demand conditions are considered with regard to: intensity of tourist traffic, its directions and structure, tourist's profile (age, permanent residence, education), expenditure during tourist events, preferences and expectations of tourists. Developments are determined and forecasts are presented.

Economic analysis of tourism's impact on the economy normally takes into account the effects of both tourism in a narrow sense (often termed the tourist industry) and broader definition (commonly referred to as the tourist economy), the latter encompassing a wider supporting sectors including catering, the souvenir industry, commerce, construction, insurance or banking. The fundamental parameters determine the comprising contribution of the tourist industry to GNP and employment. In the case of related sectors, researchers commonly encounter the difficulty of estimating the impact of tourism on development, since these sectors depend on a range of factors other than tourism.

The theory of tourist region highlights tourist attractions, treated as principal sources of tourist traffic. Broadly speaking, these include (Kusa, 2008):

- Natural attractions: landscape, climate and other geographical features.

- Man-made attractions: historic buildings and infrastructure.

- Cultural attractions: tradition and folklore, religion, museums, special events.

- Social attractions: lifestyle of residents and local communities.

Tourist attractions are the root cause of emergence of tourist regions and necessary but insufficient conditions for development of tourist traffic. They must be supplemented with a set of facilities and institutions providing the material and organisational base without which natural and cultural assets would remain unexplored or even inaccessible (Gołembski, 1998). These factors are defined as tourist infrastructure.

\section{Methods}

Factors determining tourist competitiveness were evaluated by means of the Hellwig's method (Hellwig, 1968). It provides for a construction of a synthetic measure founded on partial diagnostic variables that represent various aspects of a phenomenon under discussion (Dyr \& Ziółkowska, 2014).

Successive stages of the research involved:

- Creating a set of diagnostic characteristics.

- Normalisation of diagnostic characteristics.

- Calculation of taxonomical indices.

The diagnostic characteristics were listed considering the indicators available in public statistics of the European Union (Eurostat) concerning diverse aspects of tourist competitiveness and competitiveness of the EU-28 member states (Tab. 5). The source assured comparability and a relatively high reliability of statistics. Each factor and each diagnostic variable was assigned a unique symbol (identifier) to distinguish it from other variables and to assign them with specific numerical values. All the figures relate to 2013 - the most recent year for which full data are available.

To assess tourist competitiveness, the characteristics were normalised by standardising $j^{\text {th }}$ variable of $i^{\text {th }}$ microregion. The calculations employed the formulas below:

- Stimulants:

$$
t_{i j}=\frac{x_{i j}-\bar{x}}{\mathrm{~S}_{j}}
$$

- Destimulants:

$$
t_{i j}=-\frac{x_{i j}-\bar{x}}{\mathrm{~S}_{j}}
$$

where:

$t_{i j}$ - standardised value of $j^{\text {th }}$ index in $i^{\text {th }}$ territorial unit,

$x_{i j}-$ value of $j^{\text {th }}$ characteristic in $i^{\text {th }}$ territorial unit, $\bar{x}$ - arithmetic mean of characteristic $j$,

$S_{j}$ - standard deviation in distribution of characteristic $x_{j}$.

Using final sets of standardised diagnostic indicators, Hellwig's taxonomical indices of competitiveness, i.e. synthetic indices for each variable selected and partial indices for aspects 
Tab. 5: The diagnostic variable set of the tourism competitiveness

\begin{tabular}{|c|c|c|c|}
\hline \multicolumn{2}{|c|}{ Taxonomical Index } & \multicolumn{2}{|r|}{ Diagnostic Variables } \\
\hline Symbol & Name & Symbol & Name \\
\hline \multirow{3}{*}{$\mathrm{X} 1$} & \multirow{3}{*}{$\begin{array}{l}\text { The competitiveness } \\
\text { of the EU Member } \\
\text { States }\end{array}$} & $\mathrm{x}_{1,1}$ & GDP per capita \\
\hline & & $\mathrm{x}_{1,2}$ & Gross value added per capita \\
\hline & & $\mathrm{x}_{1,3}$ & Final consumption expenditure per capita \\
\hline \multirow{4}{*}{$\mathrm{X} 2$} & \multirow{4}{*}{$\begin{array}{l}\text { Capacity of tourist } \\
\text { accommodation } \\
\text { establishments }\end{array}$} & $\mathrm{x}_{2,1}$ & Number of hotels and similar accommodation \\
\hline & & $\mathrm{x}_{2,2}$ & Number of holiday and other short-stay accommodation \\
\hline & & $\mathrm{x}_{2,3}$ & $\begin{array}{l}\text { Number of bed-places in hotels and similar } \\
\text { accommodation }\end{array}$ \\
\hline & & $\mathrm{x}_{2,4}$ & $\begin{array}{l}\text { Number of bedrooms in hotels and similar } \\
\text { accommodation }\end{array}$ \\
\hline \multirow{5}{*}{ X3 } & \multirow{5}{*}{$\begin{array}{l}\text { Arrivals at tourist } \\
\text { accommodation } \\
\text { establishments }\end{array}$} & $x_{3,1}$ & $\begin{array}{l}\text { Arrivals number of residents at hotels and similar } \\
\text { accommodation }\end{array}$ \\
\hline & & $\mathrm{x}_{3,2}$ & $\begin{array}{l}\text { Arrivals number of non-residents at hotels and similar } \\
\text { accommodation }\end{array}$ \\
\hline & & $x_{3,3}$ & $\begin{array}{l}\text { Total arrivals number at tourist accommodation } \\
\text { establishments }\end{array}$ \\
\hline & & $\mathrm{x}_{3,4}$ & $\begin{array}{l}\text { Arrivals of residents - holiday and other short-stay } \\
\text { accommodation }\end{array}$ \\
\hline & & $\mathrm{x}_{3,5}$ & $\begin{array}{l}\text { Arrivals number of non-residents -holiday and other } \\
\text { short-stay accommodation }\end{array}$ \\
\hline \multirow{4}{*}{ X4 } & \multirow{4}{*}{$\begin{array}{l}\text { Average expenditure } \\
\text { of tourism trips } \\
\text { (1 night or over) - } \\
\text { Domestic trips }\end{array}$} & $\mathrm{x}_{4,1}$ & Average total expenditure per night \\
\hline & & $\mathrm{X}_{4,2}$ & Average expenditure on accommodation per night \\
\hline & & $\mathrm{X}_{4,3}$ & Average total expenditure per trip \\
\hline & & $\mathrm{x}_{4,4}$ & Average expenditure on accommodation per night \\
\hline \multirow{4}{*}{ X5 } & \multirow{4}{*}{$\begin{array}{l}\text { Average expenditure } \\
\text { of tourism trips ( } 1 \\
\text { night or over) - } \\
\text { Outbound trips }\end{array}$} & $\mathrm{x}_{5,1}$ & Average total expenditure per night \\
\hline & & $\mathrm{x}_{5,2}$ & Average expenditure on accommodation per night \\
\hline & & $x_{5,3}$ & Average total expenditure per trip \\
\hline & & $x_{5,4}$ & Average expenditure on accommodation per night \\
\hline
\end{tabular}

of the particular areas, were computed for each member state.

Hellwig's method employs a matrix of standardised variables to determine a standard object of the following coordinates:

$$
O=\left[x_{0 j}\right]
$$

where:

$\mathrm{x}_{0 \mathrm{j}}=\max _{\mathrm{i}}\left\{\mathrm{t}_{\mathrm{ij}}\right\}-$ for stimulants,

$x_{0 j}=\min _{i}\left\{t_{i j}\right\}$ - for destimulants,

$t_{i j}$ - standardised value of $j^{\text {th }}$ index in $i^{\text {th }}$ territorial unit.
Only the stimulants formula was used to calculate the synthetic competitiveness index of micro regions as de-stimulants were absent from the characteristics to be assessed.

Euclidean distance from the standard object was subsequently determined:

$$
d_{i 0}=\sqrt{\sum_{j=1}^{m}\left(t_{i j}-x_{0 j}\right)^{2}}
$$

where:

$d_{i 0}$ - Euclidean distance between $i^{\text {th }}$ and the standard object, 
$t_{i j}$ - standardised value of $j^{\text {th }}$ index in $i^{\text {th }}$ territorial unit,

$i=1,2, \ldots, \mathrm{n}$,

$\mathrm{j}=1,2, \ldots, \mathrm{m}$,

Given these assumptions, the synthetic index can be computed as:

$$
S_{i}=1-\frac{d_{i 0}}{d_{0}}
$$

where:

$d_{i 0}$ - Euclidean distance between $i^{\text {th }}$ and the standard object,

$d_{0}$ - critical distance of a given unit from the standard:

$$
d_{0}=\bar{d}_{i 0}+2 \cdot S_{0}
$$

$\bar{d}_{i 0}$ - arithmetic mean of taxonomical distances between $i^{\text {th }}$ and the standard object:

$$
\bar{d}_{0}=\frac{1}{n} \cdot \sum_{i=1}^{n} d_{i 0}
$$

$S_{0}$ - standard deviation of taxonomical distances between $i^{\text {th }}$ and the standard object:

$$
S_{0}=\sqrt{\frac{1}{n} \sum_{i=1}^{n}\left(d_{i 0}-\bar{d}_{0}\right)^{2}}
$$

The synthetic competitiveness index $S_{i}$ is in the range $[0,1]$ as part of this model. The maximum value of $S_{i}(1)$ represents the socalled standard, that is, a state where all the variables analysed are maximum.

In this method, the greater the synthetic index, the higher the tourist competitiveness. Differences between the indices also point to development gaps of the particular European Union member states.

\section{Competitiveness of the European Union Member States}

The competitiveness pyramid frequently serves to evaluate competitiveness of states and regions. The concept, developed for the purposes of the commission, identifies factors deciding changes of competitiveness. Factors reflecting economic development and quality of life are at the top of the pyramid (Gardiner, Martin, \& Tyler, 2004).

To evaluate competitiveness of the European Union member states in order to verify the hypotheses postulated in this article, 3 diagnostic variables at the top of the competitiveness pyramid were employed, namely:

- GDP per capita,

- Gross value added per capita,

- Final consumption expenditure per capita.

Values of diagnostic variables and the algorithm for calculation of the synthetic taxonomical index to represent competitiveness of the European Union member states are shown in Table 6 . The resultant values of the synthetic competitiveness index corroborate the universally accepted opinion on a considerably varied competitiveness of the EU-28 member states and the relatively low competitiveness of Central European states. Therefore, a detailed analysis of results is not undertaken in this respect.

\section{Sector of Tourism} and Competitiveness of the EU Member States - the Authors' Research

\section{Capacity of tourist accommodation} establishments

Availability of accommodation establishments is a major factor of tourist competitiveness. The lack of well-developed tourist facilities, in particular, accommodation establishments, restricts and often even prevents access to other tourist attractions (e.g. mountain trails, sea beaches, monuments, etc.).

The following diagnostic variables were used to construct the taxonomical index of availability of accommodation establishments.

- Number of hotels and similar accommodation.

- Number of holiday and other short-stay accommodation.

- Number of beds in hotels and accommodation facilities.

- Number of rooms in hotels and similar accommodation. 


\section{Tab. 6: Calculation of the synthetic competitiveness index of EU-28 member states}

\begin{tabular}{|c|c|c|c|c|c|c|c|c|}
\hline \multirow[t]{2}{*}{ Member State } & \multicolumn{3}{|c|}{ Variable Value } & \multicolumn{3}{|c|}{ Standardized Variable Value } & \multirow{2}{*}{$\begin{array}{c}\begin{array}{c}\text { Euclidean } \\
\text { Distance }\end{array} \\
\mathrm{d}_{1.0} \\
\end{array}$} & \multirow{2}{*}{$\begin{array}{c}\text { Synthetic } \\
\text { Index }\end{array}$} \\
\hline & $\mathbf{x}_{1,1}$ & $\mathbf{x}_{1,2}$ & $\mathbf{x}_{1,3}$ & $t_{1.1}$ & $t_{1.2}$ & $t_{1.3}$ & & \\
\hline Belgium & 35,600 & 18,274 & 31,700 & 0.621 & 0.781 & 0.609 & 4.245 & 0.507 \\
\hline Bulgaria & 5,600 & 3,525 & 4,852 & -1.179 & -1.494 & -1.175 & 7.468 & 0.132 \\
\hline Czech Republic & 14,900 & 7,430 & 13,381 & -0.621 & -0.892 & -0.608 & 6.486 & 0.246 \\
\hline Denmark & 45,100 & 22,026 & 38,905 & 1.191 & 1.360 & 1.087 & 3.386 & 0.606 \\
\hline Germany & 34,200 & 19,516 & 31,365 & 0.537 & 0.973 & 0.586 & 4.266 & 0.504 \\
\hline Estonia & 14,200 & 7,307 & 12,426 & -0.663 & -0.911 & -0.671 & 6.561 & 0.238 \\
\hline Ireland & 38,000 & 17,151 & 34,968 & 0.765 & 0.608 & 0.826 & 4.057 & 0.529 \\
\hline Greece & 16,500 & 11,819 & 14,606 & -0.525 & -0.214 & -0.527 & 6.096 & 0.292 \\
\hline Spain & 22,500 & 13,061 & 20,512 & -0.165 & -0.023 & -0.134 & 5.531 & 0.357 \\
\hline France & 32,100 & 17,936 & 28,970 & 0.411 & 0.729 & 0.427 & 4.525 & 0.474 \\
\hline Croatia & 10,200 & 6,198 & 8,657 & -0.903 & -1.082 & -0.922 & 6.947 & 0.193 \\
\hline Italy & 26,500 & 16,384 & 24,275 & 0.075 & 0.490 & 0.116 & 5.033 & 0.415 \\
\hline Cyprus & 21,000 & 14,220 & 19,270 & -0.255 & 0.156 & -0.217 & 5.583 & 0.351 \\
\hline Latvia & 11,600 & 7,116 & 10,007 & -0.819 & -0.940 & -0.832 & 6.775 & 0.213 \\
\hline Lithuania & 11,800 & 7,387 & 10,649 & -0.807 & -0.898 & -0.789 & 6.722 & 0.219 \\
\hline Luxembourg & 83,100 & 26,194 & 75,338 & 3.472 & 2.003 & 3.507 & 0.000 & 1.000 \\
\hline Hungary & 10,200 & 5,346 & 8,542 & -0.903 & -1.213 & -0.929 & 7.012 & 0.185 \\
\hline Malta & 17,800 & 10,096 & 15,626 & -0.447 & -0.480 & -0.459 & 6.103 & 0.291 \\
\hline Netherlands & 38,700 & 17,412 & 34,967 & 0.807 & 0.648 & 0.826 & 4.015 & 0.533 \\
\hline Austria & 38,100 & 20,553 & 34,021 & 0.771 & 1.133 & 0.763 & 3.947 & 0.541 \\
\hline Poland & 10,300 & 6,336 & 9,246 & -0.897 & -1.060 & -0.883 & 6.909 & 0.197 \\
\hline Portugal & 16,200 & 10,590 & 14,170 & -0.543 & -0.404 & -0.556 & 6.198 & 0.280 \\
\hline Romania & 7,200 & 4,465 & 6,357 & -1.083 & -1.349 & -1.075 & 7.278 & 0.154 \\
\hline Slovenia & 17,500 & 9,503 & 15,167 & -0.465 & -0.572 & -0.489 & 6.172 & 0.283 \\
\hline Slovakia & 13,600 & 7,713 & 12,409 & -0.699 & -0.848 & -0.673 & 6.557 & 0.238 \\
\hline Finland & 37,300 & 20,512 & 32,139 & 0.723 & 1.127 & 0.638 & 4.069 & 0.527 \\
\hline Sweden & 45,500 & 21,307 & 40,354 & 1.215 & 1.249 & 1.184 & 3.325 & 0.614 \\
\hline United Kingdom & 31,500 & 20,479 & 28,102 & 0.375 & 1.122 & 0.370 & 4.495 & 0.478 \\
\hline Arithmetic Mean & $25,242.9$ & $13,209.2$ & $22,535.0$ & 0.0 & 0.0 & 0.0 & 5.349 & 0.378 \\
\hline Standard Deviation & $16,666.1$ & $6,481.6$ & $15,055.7$ & 1.0 & 1.0 & 1.0 & 1.628 & 0.189 \\
\hline Variation Coefficient & $66.0 \%$ & $49.1 \%$ & $66.8 \%$ & & - & - & - & $50.0 \%$ \\
\hline Max & 83,100 & 26,194 & 75,338 & 3.472 & 2.003 & 3.507 & 7.468 & 1.000 \\
\hline Min & 5,600 & 3,525 & 4,852 & -1.179 & -1.494 & -1.175 & 0.000 & 0.132 \\
\hline
\end{tabular}


Values of diagnostic variables and the algorithm for calculation of the synthetic taxonomical index to represent availability of accommodation establishments are shown in Table 7. Availability of accommodation in the
EU-28 member states is greatly varied - the variation coefficient for the total numbers of establishments and beds ranges from 140\% to $220 \%$. The variation becomes even greater when numbers of establishments are referred to

\begin{tabular}{|c|c|c|c|c|c|c|c|c|c|c|}
\hline \multirow{2}{*}{ Member State } & \multicolumn{4}{|c|}{ Variable Value } & \multicolumn{4}{|c|}{ Standardized Variable Value } & \multirow{2}{*}{$\begin{array}{c}\begin{array}{c}\text { Euclidean } \\
\text { Distance }\end{array} \\
\mathrm{d}_{2,0} \\
\end{array}$} & \multirow{2}{*}{$\begin{array}{c}\text { Synthetic } \\
\text { Index }\end{array}$} \\
\hline & $x_{2,1}$ & $x_{2,2}$ & $\mathbf{x}_{2,3}$ & $x_{2,4}$ & $t_{2,1}$ & $t_{2,2}$ & $t_{2,3}$ & $t_{2,4}$ & & \\
\hline Belgium & 1,713 & 2,839 & 128,641 & 59,671 & -0.484 & -0.347 & -0.529 & -0.530 & 7.221 & 0.247 \\
\hline Bulgaria & 2,055 & 890 & 262,196 & 118,107 & -0.454 & -0.422 & -0.330 & -0.354 & 7.098 & 0.260 \\
\hline Czech Republic & 6,301 & 3,163 & 317,875 & 137,257 & -0.082 & -0.334 & -0.248 & -0.296 & 6.812 & 0.290 \\
\hline Denmark & 514 & 174 & 87,129 & 43,293 & -0.589 & -0.450 & -0.590 & -0.579 & 7.385 & 0.230 \\
\hline Germany & 34,692 & 14,105 & $1,757,624$ & 948,667 & 2.406 & 0.090 & 1.889 & 2.151 & 4.288 & 0.553 \\
\hline Estonia & 404 & 916 & 31,989 & 15,321 & -0.599 & -0.421 & -0.672 & -0.664 & 7.443 & 0.224 \\
\hline Ireland & 2,462 & 4,915 & 155,660 & 66,576 & -0.419 & -0.266 & -0.489 & -0.509 & 7.113 & 0.258 \\
\hline Greece & 9,675 & 24,014 & 773,214 & 401,196 & 0.214 & 0.474 & 0.428 & 0.500 & 5.532 & 0.423 \\
\hline Spain & 19,610 & 25,630 & $1,867,823$ & 914,263 & 1.084 & 0.537 & 2.053 & 2.048 & 4.217 & 0.560 \\
\hline France & 17,171 & 3,620 & $1,258,942$ & 629,471 & 0.871 & -0.316 & 1.149 & 1.189 & 5.399 & 0.437 \\
\hline Croatia & 897 & 60,585 & 161,957 & 77,157 & -0.556 & 1.893 & -0.479 & -0.477 & 6.029 & 0.371 \\
\hline Italy & 33,316 & 121,879 & $2,233,823$ & $1,089,770$ & 2.286 & 4.269 & 2.596 & 2.577 & 0.610 & 0.936 \\
\hline Cyprus & 792 & 138 & 84,715 & 41,782 & -0.565 & -0.451 & -0.594 & -0.584 & 7.378 & 0.231 \\
\hline Latvia & 255 & 269 & 22,594 & 11,508 & -0.612 & -0.446 & -0.686 & -0.675 & 7.476 & 0.220 \\
\hline Lithuania & 414 & 1,402 & 27,793 & 13,468 & -0.598 & -0.402 & -0.678 & -0.669 & 7.436 & 0.225 \\
\hline Luxembourg & 243 & 121 & 15,028 & 7,836 & -0.613 & -0.452 & -0.697 & -0.686 & 7.490 & 0.219 \\
\hline Hungary & 2,064 & 1,676 & 173,156 & 71,041 & -0.453 & -0.392 & -0.463 & -0.495 & 7.193 & 0.250 \\
\hline Malta & 153 & 17 & 41,626 & 18,420 & -0.621 & -0.456 & -0.658 & -0.654 & 7.465 & 0.222 \\
\hline Netherlands & 3,510 & 2,338 & 244,145 & 113,813 & -0.327 & -0.366 & -0.357 & -0.366 & 7.018 & 0.268 \\
\hline Austria & 13,073 & 6,692 & 601,483 & 293,702 & 0.511 & -0.197 & 0.173 & 0.176 & 6.105 & 0.363 \\
\hline Poland & 3,485 & 5,974 & 274,297 & 134,417 & -0.329 & -0.225 & -0.312 & -0.304 & 6.882 & 0.282 \\
\hline Portugal & 2,331 & 852 & 309,918 & 137,511 & -0.430 & -0.424 & -0.260 & -0.295 & 7.035 & 0.266 \\
\hline Romania & 2,292 & 3,013 & 214,771 & 106,542 & -0.433 & -0.340 & -0.401 & -0.388 & 7.078 & 0.262 \\
\hline Slovenia & 639 & 284 & 44,472 & 22,102 & -0.578 & -0.446 & -0.654 & -0.643 & 7.432 & 0.225 \\
\hline Slovakia & 1,439 & 1,296 & 92,261 & 38,690 & -0.508 & -0.406 & -0.583 & -0.593 & 7.322 & 0.236 \\
\hline Finland & 828 & 372 & 136,891 & 57,447 & -0.562 & -0.442 & -0.516 & -0.536 & 7.317 & 0.237 \\
\hline Sweden & 2,045 & 1,131 & 235,752 & 117,228 & -0.455 & -0.413 & -0.370 & -0.356 & 7.110 & 0.259 \\
\hline United Kingdom & 40,272 & 41,495 & $2,018,172$ & 902,998 & 2.895 & 1.152 & 2.276 & 2.014 & 3.184 & 0.668 \\
\hline Arithmetic Mean & $7,237.3$ & $11,778.6$ & $484,783.8$ & $235,330.5$ & 0.0 & 0.0 & 0.0 & 0.0 & 6.431 & 0.329 \\
\hline Standard Deviation & $11,409.0$ & $25,788.0$ & $673,651.7$ & $331,568.2$ & 1.0 & 1.0 & 1.0 & 1.0 & 1.579 & 0.165 \\
\hline Variation Coefficient & $157.6 \%$ & $218.9 \%$ & $139.0 \%$ & $140.9 \%$ & - & - & - & - & - & $50.0 \%$ \\
\hline Max & 40,272 & 121,879 & $2,233,823$ & $1,089,770$ & 2.895 & 4.269 & 2.596 & 2.577 & 7.490 & 0.936 \\
\hline Min & 153 & 17 & 15,028 & 7,836 & -0.621 & -0.456 & -0.697 & -0.686 & 0.610 & 0.219 \\
\hline
\end{tabular}


$1 \mathrm{~km}^{2}$ of a state under analysis. In consequence, the range of the synthetic competitiveness index - the quotient of maximum and minimum indices - is 4 .

Dependence between availability of accommodation establishments and competitiveness of regions is very low - Pearson correlation coefficient is 0.09 . This implies the standard of tourist facilities in the EU-28 member states is not decided by macroeconomic factors. It can be surmise tourist attractiveness of regions and eagerness of residents to provide tourist services are important.

Italy, the UK, Spain, Germany and France are among states with the top standard of tourist accommodation. These are large states. It only seems natural, therefore, that plenty of accommodation establishments are provided there. On the other hand, correlation between the taxonomical index of their availability and area of particular states is merely 0.51 (average correlation). This is due to the fact that in small countries with attractive natural conditions for tourism and happily visited by foreign tourists, there are relatively many accommodation establishments. In effect, states like Malta, Croatia or Cyprus exhibit highest values of the taxonomical index of accommodation establishments per unit of territory. This grouping also comprises large states like Italy, the United Kingdom, Austria and Greece. Both those 'small' and 'large' are highly attractive to tourists. These factors appear to be a key to location of accommodation establishments. Good conditions for tourism may encourage commitment of private capital to development of accommodation facilities and undertaking of tourism operations.

Slovakia and Poland are among states with relatively poor provision of accommodation establishments. This may suggest these states fail to take full advantage of their natural resources. This applies to Slovakia with numerous natural parks, mountain resort with long term tradition, such as High and Low Tatras etc. as well as to Poland, with a relatively long coast line, considerable area of lakes and attractive mountain trails.

\section{Arrivals at tourist accommodation establishments}

The following diagnostic variables were employed to construct the taxonomical index of tourist traffic in the EU-28 member states:
- Arrivals of residents at hotels and similar accommodation.

- Arrivals of non-residents at hotels and similar accommodation.

- Total arrivals at tourist accommodation establishments.

- Arrivals of residents - holiday and other short-stay accommodation.

- Arrivals of non-residents - holiday and other short-stay accommodation.

Values of diagnostic variables and the algorithm for calculation of the synthetic taxonomical index to represent arrivals of accommodation establishments are shown in Table 8.

There is a high, statistically significant dependence between tourist arrivals in particular states and availability of accommodation establishments. The Pearson linear correlation coefficient is 0.81 . This affirms the postulate that the availability of tourist facilities is an extremely important factor of regions' tourist competitiveness. Most tourists arrive in countries like France, Germany, Spain, Italy or the UK. These are large states with excellent availability of bed-places. The correlation between area of a state and tourist arrivals is far lower than between availability of beds and the arrivals.

There is a low correlation between tourist arrivals and competitiveness of states - the coefficient is 0.19 . This may indicate tourists pay scant attention to macroeconomic standing of countries they intend to visit. On the contrary, a weaker competitive standing may boost tourist arrivals. For instance, Bulgaria and Romania are among the EU states of the poorest competitiveness. Relatively many tourists come there. Analysis of tourist packages offered by travel agencies in Poland suggests holidays in these countries are much cheaper than in the substantially more competitive Italy, Spain or Greece.

\section{Expenditure of tourism trips}

Geographical variation of competitiveness according to volumes of travel expenditure was estimated on the basis of the following diagnostic variables:

- Average total expenditure per night.

- Average expenditure on accommodation per night.

- Average total expenditure per trip.

- Average expenditure on accommodation per night. 


\section{Tab. 8: Calculating the Taxonomical Index of Arrivals at tourist accommodation establishments}

\begin{tabular}{|c|c|c|c|c|c|c|c|c|c|c|c|c|}
\hline \multirow{2}{*}{$\begin{array}{l}\text { Member } \\
\text { State }\end{array}$} & \multicolumn{5}{|c|}{ Variable Value [000] } & \multicolumn{5}{|c|}{ Standardized Variable Value } & \multirow{2}{*}{\begin{tabular}{|c|}
$\begin{array}{c}\text { Euclidean } \\
\text { Distance }\end{array}$ \\
$\mathrm{d}_{2,0}$ \\
\end{tabular}} & \multirow{2}{*}{\begin{tabular}{|c|}
$\begin{array}{c}\text { Synthetic } \\
\text { Index }\end{array}$ \\
$\mathrm{S}_{2}$ \\
\end{tabular}} \\
\hline & $\mathbf{x}_{3,1}$ & $\mathbf{x}_{3,2}$ & $\mathbf{x}_{3,3}$ & $x_{3,4}$ & $\mathbf{x}_{3,5}$ & $t_{3,1}$ & $t_{3,2}$ & $t_{3,3}$ & $t_{3,4}$ & $t_{3,5}$ & & \\
\hline Belgium & 3,947 & 6,228 & 14,152 & 2,226 & 1,065 & -0.439 & -0.252 & -0.390 & -0.183 & -0.159 & 7.007 & 0.307 \\
\hline Bulgaria & 2,611 & 2,754 & 5,847 & 410 & 64 & -0.493 & -0.539 & -0.570 & -0.562 & -0.681 & 7.625 & 0.246 \\
\hline $\begin{array}{l}\text { Czech } \\
\text { Republic }\end{array}$ & 5,046 & 7,327 & 15,408 & 1,760 & 417 & -0.395 & -0.162 & -0.363 & -0.281 & -0.497 & 7.124 & 0.295 \\
\hline Denmark & 2,454 & 1,699 & 6,437 & 629 & 307 & -0.500 & -0.626 & -0.557 & -0.516 & -0.554 & 7.583 & 0.250 \\
\hline Germany & 94,619 & 27,603 & 149,395 & 17,273 & 2,372 & 3.239 & 1.511 & 2.543 & 2.955 & 0.522 & 2.459 & 0.757 \\
\hline Estonia & 756 & 1,798 & 2,981 & 284 & 142 & -0.569 & -0.618 & -0.632 & -0.588 & -0.640 & 7.715 & 0.237 \\
\hline Ireland & 7,012 & 1,831 & 0 & 401 & 271 & -0.315 & -0.615 & -0.697 & -0.564 & -0.573 & 7.580 & 0.250 \\
\hline Greece & 5,526 & 10,491 & 21,819 & 2,368 & 3,118 & -0.375 & 0.100 & -0.224 & -0.154 & 0.910 & 6.369 & 0.370 \\
\hline Spain & 42,569 & 41,252 & 101,673 & 5,231 & 6,564 & 1.127 & 2.637 & 1.508 & 0.443 & 2.706 & 3.470 & 0.657 \\
\hline France & 78,661 & 34,067 & 153,694 & 16,090 & 4,462 & 2.591 & 2.045 & 2.637 & 2.708 & 1.611 & 1.425 & 0.859 \\
\hline Croatia & 889 & 4,673 & 12,206 & 481 & 3,718 & -0.563 & -0.380 & -0.432 & -0.547 & 1.223 & 6.888 & 0.319 \\
\hline Italy & 42,650 & 39,989 & 103,863 & 7,060 & 6,374 & 1.131 & 2.533 & 1.556 & 0.825 & 2.607 & 3.189 & 0.685 \\
\hline Cyprus & 438 & 1,947 & 2,388 & 3 & 24 & -0.582 & -0.605 & -0.645 & -0.647 & -0.701 & 7.776 & 0.231 \\
\hline Latvia & 377 & 1,132 & 1,839 & 126 & 85 & -0.584 & -0.673 & -0.657 & -0.621 & -0.670 & 7.785 & 0.230 \\
\hline Lithuania & 647 & 1,098 & 2,460 & 534 & 143 & -0.573 & -0.675 & -0.644 & -0.536 & -0.640 & 7.723 & 0.236 \\
\hline Luxembourg & 68 & 763 & 1,044 & 27 & 54 & -0.597 & -0.703 & -0.674 & -0.642 & -0.686 & 7.828 & 0.226 \\
\hline Hungary & 3,626 & 4,007 & 9,317 & 1,094 & 162 & -0.452 & -0.435 & -0.495 & -0.419 & -0.629 & 7.442 & 0.264 \\
\hline Malta & 147 & 1,293 & 1,461 & 2 & 19 & -0.593 & -0.659 & -0.665 & -0.647 & -0.704 & 7.814 & 0.227 \\
\hline Netherlands & 11,504 & 10,017 & 34,050 & 6,645 & 1,944 & -0.133 & 0.060 & 0.041 & 0.738 & 0.299 & 5.954 & 0.411 \\
\hline Austria & 9,366 & 18,164 & 32,940 & 1,522 & 2,673 & -0.219 & 0.733 & 0.017 & -0.330 & 0.679 & 6.111 & 0.396 \\
\hline Poland & 12,429 & 4,687 & 23,401 & 5,505 & 489 & -0.095 & -0.379 & -0.190 & 0.501 & -0.459 & 6.652 & 0.342 \\
\hline Portugal & 6,142 & 7,783 & 15,901 & 456 & 216 & -0.350 & -0.124 & -0.352 & -0.553 & -0.602 & 7.258 & 0.282 \\
\hline Romania & 4,961 & 1,595 & 7,919 & 1,185 & 106 & -0.398 & -0.634 & -0.525 & -0.400 & -0.659 & 7.517 & 0.257 \\
\hline Slovenia & 613 & 1,640 & 3,340 & 350 & 340 & -0.574 & -0.631 & -0.625 & -0.575 & -0.537 & 7.670 & 0.241 \\
\hline Slovakia & 1,704 & 1,423 & 4,003 & 606 & 175 & -0.530 & -0.649 & -0.610 & -0.521 & -0.623 & 7.662 & 0.242 \\
\hline Finland & 6,857 & 2,458 & 10,840 & 396 & 173 & -0.321 & -0.563 & -0.462 & -0.565 & -0.624 & 7.483 & 0.260 \\
\hline Sweden & 14,069 & 3,469 & 24,608 & 1,699 & 424 & -0.029 & -0.480 & -0.163 & -0.293 & -0.493 & 7.001 & 0.308 \\
\hline $\begin{array}{l}\text { United } \\
\text { Kingdom }\end{array}$ & 54,014 & 18,788 & 104,768 & 12,570 & 2,476 & 1.592 & 0.784 & 1.575 & 1.974 & 0.576 & 3.574 & 0.647 \\
\hline $\begin{array}{l}\text { Arithmetic } \\
\text { Mean }\end{array}$ & $14,775.2$ & $9,284.9$ & $30,991.3$ & $3,104.8$ & $1,370.6$ & 0.0 & 0.0 & 0.0 & 0.0 & 0.0 & 6.489 & 0.358 \\
\hline $\begin{array}{l}\text { Standard } \\
\text { Deviation }\end{array}$ & $24,653.5$ & $12,120.8$ & $45,647.4$ & $4,794.5$ & $1,919.4$ & 1.0 & 1.0 & 1.0 & 1.0 & 1.0 & 1.811 & 0.179 \\
\hline $\begin{array}{l}\text { Variation } \\
\text { Coefficient }\end{array}$ & $166.9 \%$ & $130.5 \%$ & $143.4 \%$ & $154.4 \%$ & $140.0 \%$ & - & - & - & - & - & $27.9 \%$ & $50.0 \%$ \\
\hline Max & 94,619 & 41,252 & 153,694 & 17,273 & 6,564 & 3.239 & 2.637 & 2.637 & 2.955 & 2.706 & 7.828 & 0.859 \\
\hline Min & 68 & 763 & 0 & 2 & 19 & -0.597 & -0.703 & -0.697 & -0.647 & -0.704 & 1.425 & 0.226 \\
\hline
\end{tabular}

Source: own 
Tab. 9:

Calculating the Taxonomical Index of average expenditure of tourism trips (1 night or over) - domestic trips

\begin{tabular}{|c|c|c|c|c|c|c|c|c|c|c|}
\hline \multirow{2}{*}{ Member State } & \multicolumn{4}{|c|}{ Variable Value } & \multicolumn{4}{|c|}{ Standardized Variable Value } & \multirow{2}{*}{$\begin{array}{c}\begin{array}{c}\text { Euclidean } \\
\text { Distance }\end{array} \\
\mathrm{d}_{6,0}\end{array}$} & \multirow{2}{*}{$\begin{array}{c}\begin{array}{c}\text { Synthetic } \\
\text { Index }\end{array} \\
\mathrm{S}_{6}\end{array}$} \\
\hline & $\mathbf{x}_{6,1}$ & $\mathbf{x}_{6,2}$ & $\mathbf{x}_{6,3}$ & $\mathbf{x}_{6,4}$ & $t_{6,1}$ & $t_{6,2}$ & $\mathbf{t}_{6,3}$ & $\mathbf{t}_{6,4}$ & & \\
\hline Belgium & 76.35 & 24.69 & 317.62 & 102.71 & 1.136 & 0.866 & 1.720 & 1.318 & 2.888 & 0.670 \\
\hline Bulgaria & 24.44 & 6.05 & 106.76 & 26.43 & -0.823 & -0.767 & -0.614 & -0.632 & 6.522 & 0.255 \\
\hline Czech Republic & 16.75 & 3.74 & 60.04 & 13.4 & -1.113 & -0.970 & -1.132 & -0.966 & 7.165 & 0.182 \\
\hline Denmark & 86.46 & 28.03 & 203.67 & 66.03 & 1.518 & 1.158 & 0.459 & 0.380 & 3.566 & 0.593 \\
\hline Germany & 77.88 & 32.17 & 274.23 & 113.29 & 1.194 & 1.521 & 1.240 & 1.588 & 2.345 & 0.732 \\
\hline Estonia & 29.67 & 6.19 & 64.82 & 13.51 & -0.626 & -0.755 & -1.079 & -0.963 & 6.813 & 0.222 \\
\hline Ireland & 71.90 & 26.18 & 199.23 & 72.55 & 0.968 & 0.996 & 0.409 & 0.547 & 3.693 & 0.578 \\
\hline Greece & 25.58 & 4.26 & 261.13 & 43.46 & -0.780 & -0.924 & 1.095 & -0.197 & 5.884 & 0.328 \\
\hline Spain & 32.11 & 7.13 & 147.7 & 32.82 & -0.533 & -0.673 & -0.161 & -0.469 & 6.076 & 0.306 \\
\hline France & 50.03 & 12.73 & 258.47 & 65.78 & 0.143 & -0.182 & 1.065 & 0.374 & 4.650 & 0.469 \\
\hline Croatia & 31.80 & 7.25 & 152.05 & 34.68 & -0.545 & -0.662 & -0.113 & -0.422 & 6.031 & 0.311 \\
\hline Italy & 52.78 & 20.15 & 319.5 & 121.96 & 0.247 & 0.468 & 1.741 & 1.810 & 3.376 & 0.615 \\
\hline Cyprus & 38.20 & 8.87 & 136.91 & 31.8 & -0.304 & -0.520 & -0.281 & -0.495 & 5.946 & 0.321 \\
\hline Latvia & 17.81 & 2.86 & 41.13 & 6.6 & -1.073 & -1.047 & -1.341 & -1.139 & 7.378 & 0.158 \\
\hline Lithuania & 18.10 & 5.45 & 49.44 & 14.88 & -1.062 & -0.820 & -1.249 & -0.928 & 7.091 & 0.190 \\
\hline Luxembourg & 93.80 & 20.25 & 192.2 & 41.5 & 1.795 & 0.477 & 0.332 & -0.247 & 4.415 & 0.496 \\
\hline Hungary & 20.28 & 8.36 & 64.81 & 26.7 & -0.980 & -0.565 & -1.079 & -0.626 & 6.675 & 0.238 \\
\hline Malta & 49.54 & 17.94 & 122.25 & 44.28 & 0.124 & 0.274 & -0.443 & -0.176 & 5.208 & 0.405 \\
\hline Netherlands & 29.04 & 13.08 & 109.23 & 49.2 & -0.649 & -0.151 & -0.587 & -0.050 & 5.769 & 0.341 \\
\hline Austria & 102.12 & 49.52 & 341.63 & 165.67 & 2.109 & 3.041 & 1.986 & 2.927 & 0.000 & 1.000 \\
\hline Portugal & 18.11 & 3.59 & 79.48 & 15.75 & -1.062 & -0.983 & -0.916 & -0.906 & 7.026 & 0.198 \\
\hline Romania & 23.60 & 4.89 & 90.52 & 18.76 & -0.855 & -0.869 & -0.794 & -0.829 & 6.775 & 0.226 \\
\hline Slovenia & 36.61 & 15.04 & 96.93 & 39.82 & -0.364 & 0.020 & -0.723 & -0.290 & 5.738 & 0.345 \\
\hline Slovakia & 35.60 & 11.37 & 118.65 & 37.9 & -0.402 & -0.301 & -0.483 & -0.339 & 5.851 & 0.332 \\
\hline Finland & 71.52 & 15.25 & 194.23 & 41.42 & 0.954 & 0.039 & 0.354 & -0.249 & 4.806 & 0.451 \\
\hline United Kingdom & 72.26 & 29.97 & 215.78 & 89.49 & 0.982 & 1.328 & & 0.980 & 2.828 & 0.677 \\
\hline Arithmetic Mean & 46.20 & 14.80 & 162.20 & 51.2 & 0.000 & 0.000 & 0.000 & 0.000 & 5.174 & 0.409 \\
\hline Standard Deviation & 26.50 & 11.40 & 90.30 & 39.10 & 1.000 & 1.000 & 1.000 & 1.000 & 1.792 & 0.205 \\
\hline Variation Coefficient & $57.3 \%$ & $77.1 \%$ & $55.7 \%$ & $76.4 \%$ & - & - & - & - & $34.6 \%$ & $50.0 \%$ \\
\hline Max & 102.10 & 49.50 & 341.60 & 165.70 & 2.109 & 3.041 & 1.986 & 2.927 & 7.378 & 1.000 \\
\hline Min & 16.80 & 2.90 & 41.10 & 6.60 & -1.113 & -1.047 & -1.341 & -1.139 & 0.000 & 0.158 \\
\hline
\end{tabular}

Synthetic competitiveness indices as per the expenditure criterion were calculated for domestic and foreign trips separately - the results are summarised in Tables 9 and 10 . Two states, Poland and Sweden, were excluded as Eurostat fails to provide reliable data concerning the variables analysed.
The figures in Tables 9 and 10 suggest spending on foreign trips is far greater than on domestic travel. This is due to substantial diversity of prices in countries of destination. In addition, costs of transport are much higher in the case of foreign travel. 


\begin{tabular}{|c|c|c|c|c|c|c|c|c|c|c|}
\hline b. 10: $\begin{array}{l}\text { Ca } \\
\text { (1 }\end{array}$ & $\begin{array}{l}\text { ng } \\
\text { r o }\end{array}$ & $\begin{array}{l}\operatorname{ax} \\
-\mathrm{d}\end{array}$ & $\begin{array}{l}\text { omic } \\
\text { nesti }\end{array}$ & $\begin{array}{l}\text { ide } \\
\text { ps }\end{array}$ & 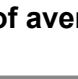 & 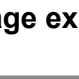 & 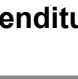 & & ISII & \\
\hline Member State & & Variabl & e Value & & Sta & ardized & riable Va & & $\begin{array}{l}\text { Euclidean } \\
\text { Distance }\end{array}$ & $\begin{array}{l}\text { Synthetic } \\
\text { Index }\end{array}$ \\
\hline & $x_{6,1}$ & $\mathbf{x}_{6,2}$ & $\mathbf{x}_{6,3}$ & $\mathbf{x}_{6,4}$ & $t_{6,1}$ & $\mathbf{t}_{6,2}$ & $t_{6,3}$ & $t_{6,4}$ & $d_{6,0}$ & $\mathrm{~S}_{6}$ \\
\hline Belgium & 123.47 & 38.51 & 988.42 & 308.28 & 1.214 & 0.958 & 1.415 & 1.112 & 2.237 & 0.714 \\
\hline Bulgaria & 42.98 & 13.01 & 329.26 & 99.69 & -1.207 & -0.980 & -1.335 & -1.055 & 6.534 & 0.165 \\
\hline Czech Republic & 61.62 & 15.78 & 422.13 & 108.13 & -0.647 & -0.770 & -0.947 & -0.967 & 5.931 & 0.242 \\
\hline Denmark & 103.12 & 37.48 & 657.62 & 239.03 & 0.602 & 0.879 & 0.035 & 0.393 & 3.275 & 0.582 \\
\hline Germany & 102.73 & 43.89 & 875.85 & 374.19 & 0.590 & 1.366 & 0.945 & 1.797 & 2.172 & 0.722 \\
\hline Estonia & 68.48 & 25.94 & 466.34 & 176.67 & -0.440 & 0.002 & -0.763 & -0.255 & 4.957 & 0.367 \\
\hline Ireland & 105.82 & 29.04 & 824.29 & 226.19 & 0.683 & 0.238 & 0.730 & 0.259 & 3.499 & 0.553 \\
\hline Greece & 49.05 & 10.00 & 630.42 & 128.52 & -1.025 & -1.209 & -0.079 & -0.755 & 5.996 & 0.234 \\
\hline Spain & 76.58 & 17.67 & 700.95 & 161.69 & -0.196 & -0.626 & 0.216 & -0.411 & 4.952 & 0.367 \\
\hline France & 113.79 & 32.55 & 991.00 & 283.5 & 0.923 & 0.505 & 1.425 & 0.855 & 2.827 & 0.639 \\
\hline Croatia & 57.68 & 15.86 & 427.90 & 117.68 & -0.765 & -0.764 & -0.923 & -0.868 & 5.924 & 0.243 \\
\hline Italy & 100.16 & 34.49 & 822.20 & 283.17 & 0.513 & 0.652 & 0.721 & 0.851 & 3.017 & 0.615 \\
\hline Cyprus & 83.98 & 18.10 & 939.43 & 202.43 & 0.026 & -0.593 & 1.210 & 0.013 & 4.455 & 0.431 \\
\hline Latvia & 59.76 & 17.26 & 381.28 & 110.11 & -0.703 & -0.657 & -1.118 & -0.947 & 5.953 & 0.239 \\
\hline Lithuania & 58.47 & 13.24 & 452.17 & 102.4 & -0.741 & -0.963 & -0.822 & -1.027 & 6.072 & 0.224 \\
\hline Luxembourg & 119.48 & 40.10 & 779.98 & 261.77 & 1.094 & 1.078 & 0.545 & 0.629 & 2.613 & 0.666 \\
\hline Hungary & 53.98 & 12.79 & 303.88 & 71.99 & -0.876 & -0.997 & -1.441 & -1.343 & 6.574 & 0.160 \\
\hline Malta & 131.38 & 29.66 & $1,020.15$ & 230.28 & 1.453 & 0.285 & 1.547 & 0.302 & 3.109 & 0.603 \\
\hline Netherlands & 73.08 & 27.18 & 705.41 & 262.39 & -0.302 & 0.097 & 0.234 & 0.636 & 4.073 & 0.480 \\
\hline Austria & 146.93 & 63.28 & 906.75 & 390.5 & 1.920 & 2.840 & 1.074 & 1.967 & 0.493 & 0.937 \\
\hline Portugal & 39.45 & 9.97 & 408.70 & 103.27 & -1.314 & -1.211 & -1.003 & -1.018 & 6.572 & 0.160 \\
\hline Romania & 39.31 & 9.55 & 369.40 & 89.75 & -1.318 & -1.243 & -1.167 & -1.158 & 6.723 & 0.141 \\
\hline Slovenia & 58.24 & 19.32 & 307.85 & 102.14 & -0.748 & -0.501 & -1.424 & -1.029 & 6.070 & 0.225 \\
\hline Slovakia & 72.20 & 25.32 & 567.93 & 199.16 & -0.328 & -0.045 & -0.339 & -0.021 & 4.640 & 0.407 \\
\hline Finland & 151.53 & 38.94 & 872.87 & 224.32 & 2.059 & 0.990 & 0.933 & 0.240 & 2.604 & 0.667 \\
\hline United Kingdom & 67.55 & 34.72 & 728.71 & 374.49 & -0.468 & 0.670 & & 1.800 & 3.335 & 0.574 \\
\hline Arithmetic Mean & 83.10 & 25.90 & 649.30 & 201.20 & 0.0 & 0.0 & 0.0 & 0.0 & 4.408 & 0.437 \\
\hline Standard Deviation & 33.20 & 13.20 & 239.8 & 96.20 & 1.0 & 1.0 & 1.0 & 1.0 & 1.710 & 0.218 \\
\hline Variation Coefficient & $40.0 \%$ & $50.8 \%$ & $36.9 \%$ & $47.8 \%$ & - & - & - & - & - & $50.0 \%$ \\
\hline Max & 152 & 63 & 1,020 & 391 & 2.059 & 2.840 & 1.547 & 1.967 & 6.723 & 0.937 \\
\hline Min & 39 & 10 & 304 & 72 & -1.318 & -1.243 & -1.441 & -1.343 & 0.493 & 0.141 \\
\hline
\end{tabular}

There is a high, statistically significant dependence between volumes of tourism expenditure and competitiveness of the EU member states. The Pearson linear correlation coefficient equals 0.76 for spending on outbound trips and 0.65 on domestic travel. This difference arises from greater opportunities for using tourist services available to residents of highly competitive regions, since a greater competitiveness of states and regions generates higher household incomes and the potential for greater spending on tourist services.

The correlation coefficient between competitiveness of states and tourism 
expenditure is lower in respect of domestic travel. Fluctuations in this grouping are much greater, though - the variation coefficient for the variable under consideration ranges from $55 \%$ to $77 \%$. For parallel factors in foreign trips, the same variations are from $36 \%$ to $50 \%$.

Spending on tourism is at a maximum in highly competitive states - Austria, Germany, UK. Average spending of an Austrian on an inbound trip is nearly eight times that of a Latvia.

Average expenditure of Slovak citizens on domestic trips are approx. $25 \%$ lower than the EU average and as much as 3-4 times lower than in the most competitive states. On the other hand, this spending is around 2-3 times greater than in countries of minimum competitiveness. The differences are somewhat narrower in the case of foreign travel. Expenditure by Slovaks are approx. 15\% lower than the EU average, twice lower than in the states with maximum standards of competitiveness and twice greater than in the least competitive countries. This variation reflects Slovakia's standing in the competitiveness ranking of the European Union member states.

\section{Conclusion}

Tourism is currently one of the most dynamically developing sectors of economy. It provides huge opportunities for socio-economic development. The international 'tourist industry' is among the fastest growing branches of the economy. It is therefore important to determine factors that improve competitiveness of tourism to the maximum extent.

In theory, the creation and promotion of a competitive market are offer based on local heritage, standards of tourist attractiveness or infrastructure development, are key to enhancing competitiveness and provision of continuing competitive advantage.

Analysis of statistics concerning competitiveness of tourism in the European Union countries was based on Hellwig's method and demonstrated all the hypotheses postulated are correct.

1. There is a considerable geographical diversity of accommodation establishments in the European Union member states. This is proved with the variation coefficient for the total number of accommodation establishments and beds ranging from $140 \%$ to $220 \%$. What is more, dependence between availability of accommodation establishments and competitiveness of regions is very weak (Pearson correlation coefficient of 0.09). This means that the standard of tourist facilities in the EU-28 member states is decided not by macroeconomic factors but tourist attractiveness of regions and readiness of their populations to provide tourist services.

2. There is a high, statistically significant dependence between tourist arrivals to individual states and availability of accommodation establishments there. Pearson correlation coefficient is 0.81 . This implies availability of tourist facilities is an extremely important factor to tourist competitiveness of regions

3. Tourism expenditure is far greater on outbound rather than domestic travel. There is a high, statistically significant dependence between competitiveness of the European Union member states and spending on tourist services. Pearson correlation coefficient is 0.76 for spending on outbound trips and 0.65 on inbound travel. This arises from the fact that residents of highly competitive regions tend to use tourist services more frequently since a greater competitiveness of states leads to higher household incomes and, as a consequence, allows for higher expenditure on tourism services.

In general, competitiveness of tourism is a complex phenomenon from the viewpoint of both theory and economic practice. This is due to two fundamental elements. First, it is affected by multiple factors, all of which must be treated in an international context. Second, two levels of analysis, macroeconomic and microeconomic, overlap.

\section{References}

Aaker, D. A. (1989). Managing Assets and Skills: The Key to a Sustainable Competitive Advantage. California Management Review, 31(2), 91-106. doi:10.2307/41166561.

Alarcon, A. L. (2004). Regional Competitiveness; the need for coordination between public and private action. In S. Rudolf (Ed.), Emerging Markets. Social, Political and Economic Challenges (pp. 87-92). Łódź: University Press.

Barney, J. B. (1991). Firm Resources and Sustained Competitive Advantage. 
Journal of Management, 17(1), 99-120. doi:10.1177/014920639101700108.

Bray, J. F. L. (1941). The Pure Theory of Capital by Friedrich A. Hayek. International Affairs Review Supplement, 19(6), 327-328. doi:10.2307/3026390.

Cabaj, W., \& Kruczek, Z. (2007). Podstawy geografii turystycznej. Kraków: Wydawnictwo Proksenia.

Dyr, T., \& Ziółkowska, K. (2014). Economic infrastructure as factor of the region's competitiveness. Central European Review of Economics \& Finance, 6(3), 5-22.

Fahey, L. (1989). Discovering Your Firm's Strongest Competitive Advantages. In L. Fahey (Ed.), The Strategic Planning Management Reader (pp. 113-118). Englewood Cliffs, NJ: Prentice-Hall.

Frączek, P. (2009). Determinanty konkurencyjności sektorów i przedsiębiorstw. Ujęcie teoretyczne. Zeszyty Naukowe Uniwersytetu Rzeszowskiego Przedsiębiorstwo i Region. Konkurencyjność a innowacyjność, 1(1), 7-17.

Gardiner, B., Martin, R., \& Tyler, P. (2004). Competitiveness, Productivity and Economic Growth across the European Regions, University of Cambridge. doi:10.1080/0034340 042000292638.

Gołembski, G. (1998). Przedsiębiorstwo turystyczne $w$ gospodarce wolnorynkowej. Poznań: Akademia Ekonomiczna w Poznaniu.

Hellwig, Z. (1968). Zastosowanie metody taksonomicznej do typologicznego podziału krajów ze względu na poziom ich rozwoju i strukturę wykwalifikowanych kadr. Przegląd Statystyczny, 14(4). 307-327.

Huggins, R. (2003). Creating a UK competitiveness Index: regional and local benchmarking. Regional Studies, 37(1), 89-96. doi:10.1080/0034340022000033420.

Hunziker, H., \& Krapf, K. (1942). Grundriss der allgemeinen Fremdenverkehrslehre. Zurich: Polygraphischer Verlag.

Kusa, R. (2008). Uwarunkowania rozwoju klastrów turystycznych. In Zarządzanie gospodarkamiopartymina wiedzy (pp.511-520). Kraków: Szkoła Letnia Zarządzania.

Marková, V., Maráková, V., Hiadlovský, V., \& Wolak-Tuzimek, A. (2014). The concept of Corporate Social Responsibility in selected economic sectors. Radom: Wydawnictwo Naukowe Spatium.

Markovics, K. (2005). Competitiveness of domestic small and medium enterprises in the
European Union. European Integration Studies, 1(4), 13-21.

Mcintosh, R. W., \& Goeldner, C. R. (1986). Tourism: Principles, Practices, Philosophy. New York: John Wiley \& Sons.

Nawrot, Ł., \& Zmyślony, P. (2009). Międzynarodowa konkurencyjność regionu turystycznego, Od programowania rozwoju do zarządzania strategicznego. Kraków: Proksenia.

Panasiuk, A. (2006). Ekonomika Turystyki. Warszawa: Wydawnictwo Naukowe PWN.

Polska Organizacja Turystyczna. (2012). Marketingowa strategia Polski w sektorze turystyki na lata 2012-2020.

Pompurová, K., \& Šimočková, I. (2014). Destination attractiveness of Slovakia: Perspectives of demand from major tourism source markets. E\&M Ekonomie a Management, 17(3), 62-73. doi:10.15240/ tul/001/2014-3-006.

Porter, M. E. (1985). Competitive Advantage: Creating and Sustaining Superior Performance. New York: The Free Press.

Porter, M. E. (1990). Competitive Advantage of Nations. London: Macmillan. doi:10.1007/ 978-1-349-11336-1.

Porter, M. E. (2001). Porter o konkurencji. Warszawa: Polskie Wydawnictwo Ekonomiczne.

Przecławski, K. (1996). Deontology of tourism. International Journal of Tourism Research, 2(3-4), 239-245. doi:10.1002/ pth.6070020305.

Rue, L. W., \& Holland, P. G. (1989). Strategic Management: Concepts and Experiences. New York: McGraw-Hill Book Company.

Sieradzka, K. (2015). Konkurencyjność małych i średnich przedsiębiorstw w Polsce. Stan aktualny i perspektywy rozwoju. In Konkurencyjność przedsiębiorstw w XXI wieku. Czynniki wzrostu (pp. 49-60). Warszawa: PWE.

Ślusarczyk, B. (2011). Międzynarodowa pozycja konkurencyjna Polski. Teoria i praktyka. Warszawa: CeDeWu.

Stoner, J. A. F. (1982). Management. Englewood Cliffs, New Jersey: Prentice-Hall, Inc.

Wernerfelt, B. (1984). A Resource-Based View of the Firm. Strategic Management Journal, 5(2), 171-180. doi:10.1002/smj.4250050207.

Wolak-Tuzimek, A., Duda, J., Sołoma, A., \& Lament, M. (2015). Zarządzanie małym I średnim przedsiębiorstwem. Wybrane problémy. Radom: Instytut Naukowo-Wydawniczy Spatium. 
Assoc. Prof. Vanda Maráková, Ph.D. Matej Bel University in Banská Bystrica Faculty of Economics Department of Tourism and Hospitality vanda.marakova@umb.sk

Assoc. Prof. Tadeusz Dyr, Ph.D. University of Technology and Humanities in Radom Faculty of Economics Department of Economy t.dyr@uthrad.pl
Anna Wolak-Tuzimek, Ph.D. University of Technology and Humanities in Radom Faculty of Economics Department of Economy awt@uthrad.pl 


\section{Abstract}

\section{FACTORS OF TOURISM'S COMPETITIVENESS INTHE EUROPEAN UNION COUNTRIES}

\section{Vanda Maráková, Tadeusz Dyr, Anna Wolak-Tuzimek}

Tourism is one of the most rapidly blossoming sectors of economy and its economic and social significance is expressed both in numbers (share in GNP, employment) and in a range of as important uncountable characteristics like expansion of a region, more intense development, building the spirit of local communities, actions preventing social exclusion or education of future generations for state progress. A number of countries, provinces and regions have achieved wellrounded social and economic growth by developing tourist economies and a range of necessary supporting measures, including complementary infrastructure, active and well-educated society by organising adequate living standards and fulfilling basic social requirements, etc. It is therefore important to determine factors that improve competitiveness of tourism to maximum extent.

The objective of this paper is to evaluate dependences between competitiveness of the European Union member states and selected factors determining competitiveness of tourism in these states. A set of factors determining competitiveness of tourism is introduced, that is, capacity of tourist accommodation establishments, arrivals at tourist accommodation establishments, average expenditure of tourism trips (1 night or over) - domestic trips, average expenditure of tourism trips (1 night or over) - outbound trips, tourism domestic trips (1 night or over), tourism outbound trips (1 night or over) and their impact on levels of competitiveness is determined. Considerable geographical variation of availability of accommodation establishments in the European Union member states and high, statistically significance correlations between availability of accommodation establishments and numbers of tourists arriving in a given states and between competitiveness of the EU states and tourism expenditure are identified.

Key Words: Competitiveness, tourism, sources of competitive advantage.

JEL Classification: L83, C15.

DOI: 10.15240/tul/001/2016-3-007 